PARECERES

\title{
Consultoria Geral da República
}

- Lei $n^{9} 4.380-64$, art. 65, § $5^{\circ}$. Possibilidade legal de aquisição de imóveis pelos ocupantes.

- As Leis ns. 3.990, de 7-12-61 e 4.581 , de 11-12-64 não são inconstitucionais.

- Exigência de diploma para efeito de readaptação. Art. $3^{\circ}$ da Lei $\mathrm{n}^{\circ}$ 4.084, de 1962. Aplicação.

- Servidores da extinta Comissão Federal de Abastecimento e Preços (COFAP). Competência da Superintendência Nacional do Abastecimento (SUNAB) para julgar atos praticados pelo pessoal pertencente ao Órgão incorporado «ex vi» da Lei Delegada $n^{\circ} 5$, de 1962.

- Professôres da Faculdade de Farmácia e Odontologia de Juiz de Fora. Solicitação de efetivação como catedráticos. Impossibilidade de atendimento, face a preceito constitucional. Jurisprudência do Supremo Tribunal Federal.

- Acumulação de cargos. Conceito de cargo técnico ou cientifico inserto no artigo $3^{\circ}$ do Decreto número 35.956, de 1954. Apreciação.

- Retificação de enquadramento. Nivel Universitário. Enfermeiro. Aplicação do parecer do Conselho Federal de Educação.

- Ato Institucional. Demissão como consequiência da suspensão de di reitos politicos. Autoridade competente para baixar 0 ato.

PR 12.711-65- N 269-H, de 18 de novembro de 1965. - «Aprovo. Em
19-11-65» - (Enc. ao GTB, em 10-12-65).

Assunto: Lei $n^{2}$ 4.380-64, art. 65

$\S 5^{\circ}$. Possibilidade legal de aquisição de imóveis pelos ocupantes.

\section{PARECER}

Pede-se o pronunciamento desta Consultória acêrca da interpretação da Lei $\mathrm{n}^{\circ} 4.380-64$, art. $65 \S 5^{\circ}$, com vista à impossibilidade legal da aquisição de imóveis pelos ocupantes.

Sôbre a matéria, o ilustre Consultor Juridico do GTB, Dr. Igor Tenório, emitiu judicioso parecer que adoto integralmente, do seguinte teor:

\section{HISTÓRICO}

A Lei $\mathrm{n}^{2} 4.380-64$, art. $65, \S 5^{\circ}$ es. tabelece:

«Os imóveis residenciais, que deixarem de ser alienados aos ocupantes, por desinterêsse ou impossibilidade legal dos mesmos, serão objeto da aquisição pela União que poderá, para resgatá-los, solicitar a abertura de crédito especial, dar em pagamento imóveis não necessários aos seus serviços ou ações de sua propriedade em emprêsas de economia mista, mantida, nesta hipótese, a situação majoritária da União».

Os Decretos ns. 55.738, art. 31 e 55.955 , art. 23 , respectivamente, de 4 de fevereiro e 20 de abril de 1965 dizem, in verbis:

«O GTB se articulará com as entidades de que trata êste decreto, no sentido de selecionar para exclusão da venda, as unidades residenciais ocupadas pelas pessoas que exerçam na Capital Federal encargos ou funções caracterís- 
ticamente transitórias, que ficarão reservadas para permanente redistribuição aos exercentes de tais encargos e funções».

Esta mesma redação foi repetida no art. 18 , do Decreto $\mathrm{n}^{0} 56.793$, de 27 de agôsto de 1965 , que revogou os anteriores.

A Portaria $n^{\circ} 42-65$, do GTB, procurou interpretar os critérios de exclusão de venda contidos na Lei $n^{0} 4.380$ de 1964 e ampliados nos decretos mencionados.

Trata-se de caracterizar as limitações previstas na lei; de examinar a legitimidade do vigor contido no decreto e, em decorrência, estudar a exeqüibilidade da portaria, tudo à luz das conseqüências de ordem política, econômica e processual, que resultarem para os objetivos do Govêrno, na execução do $\mathrm{Pla}$ no Nacional de Habitação, em Brasília.

\section{DE MERITIS}

Do ponto de vista politico, no caso especifico de Brasilia, intenta-se a obtenção do capital necessário ao prossegui. mento das construções, sem o que não se processará a transferência dos órgãos governamentais, inda, ausentes da Capital, pela alegação de que os seus componentes humanos não dispõem de residências.

Os inconvenientes dessa dualidade de capitais políticas são múltiplos, avultando, dentre êles, o de desperdicio de tempo nas constantes e dispendiosas viagens entre Brasilia e Rio de Janeiro.

Do ponto de vista econômico, o Fun. do Rotativo só poderá funcionar se o número de adquirentes fôr suficiente para acionar o mecanismo, que proporcionará o fluxo de capital para novos investimentos.

Do ponto de vista processual, quantu menos áreas de atrito forem criadas entre Govêrno e ocupantes, reduzindose, ao minimo, reclamações, ações judiciárias etc., maiores serão os resultados positivos no setor administrativo.

A êste propósito, embora sem cabımento, já se levanta, dentre as objeções às restrições assinaladas na Portaria, a de que tais restrições conflituam-se com o disposto no art. 16, da Lei $\mathrm{n}^{\circ} 4.494$ de 1964 (Locação de Prédios Urbanos), que assegura ao locatário a preferência para a aquisição da residência.

Desde já é conveniente debater-se essa tese.

Não há conflito, porque a Lei núnie ro 4.494-64 não se aplica à espécie. Os imóveis arrendados pela União aos órgãos da Administração Indireta e dados aos servidores pủblicos, em ocupasão, como residência, são sujeitos ao regime do Decreto-lei $\mathrm{n}^{\circ} 9.760$, de 5 de setembro de 1946, pois ditas ocupações são do interêsse público.

$\mathrm{O}$ art. 87 , do referido diploma legal, é incisivo:

«A locação dos imóveis da Unnião se fará mediante contratos, não ficando su. jeita a disposições de outras leis concernentes à locação».

Interpretado o mandamento do texto legal, o Egrégio Tribunal Federal de Recursos decidiu:

«Locações de Apartamentos pelo GTB - Sujeitam-se às regras do Direito Público. É uma relação locativa sui generis a que dai se origina, não regida pelo Direito Civil (Apelação Cível número 1.999, Acórdão publicado in Diário da Justiça, 23-12-64, pág. 4.677).

Em idêntico sentido, aquela Egrégia Côrte já se pronunciou em outros arestos.

Mas não nos alongaremos no exame das inúmeras outras objeções surgidas e focalizaremos, apenas, o problema em tela, que, assim, poderá ser ordenado:

a) o art. 18, do Decreto $n^{\circ}$ 56.793-65. deve ser considerado regulamentação de parte do $\S 5^{\circ}$, do art. 65 , da Lei número 4.380-64 e, em conseqüência, é válida a Portaria $\mathrm{n}^{2} 42-65$ do GTB?

b) ou a norma regulamentar é contrária a expressa disposição de lei, indevidamente, restringindo-a?

Parece-nos que o ponto a discutir será o valor da expressão impossibilidade legal, contida na lei, o qual, uma vez definido, resolverá tôdas as dúvidas.

A Lei $n^{\circ}$ 4.380-64 determina aos IAPs, IPASE, autarquias em geral e sociedade de economia mista que vendam os seus imóveis, em Brasilia, aos ocupantes, salvos, duas hipóteses:

a) desinterêsse; 
b) impossibilidade legal.

Em direito, conceitua-se como impossivel não só aquilo que o é dentro da ordem natural das coisas, senão, tam. bém, tudo que é contrário às leis ou aos bons costumes (conf. verbete in posible. Dicionário de Derecho Usual, de Guiller. mo Cabanellas, pág. 272, Editorial Atalaya, B. Aires).

Poderiamos citar, ainda, no mesmo sentido, os ensinamentos de Nehemias Gueiros (verbete impossibilidade. Repertório Enciclopédio de Direito Brasileiro, volume 25, pág. 220-26) e de Arnaldo Medeiros da Fonseca (Caso fortuito e teoria da previsão).

Fixemo-nos nesta premissa: impossibilidade legal exprime o que se não pode fazer, por fôrça de dispositivos de lei, - que acarreta a invalidade da obrigação geral, porém, sòmente, nas hipóteses em que ela mesma - a Lei - previu exceções à regra geral.

E pois, na prọpria Lei $n^{9} 4.380-64$. que deveremos procurar e, realmente, vamos encontrar o único caso de impos. sibilidade legal de venda, aplicável aos ocupantes de Brasilia:

Art. $9^{\circ}, \S 1^{\circ}$

«As pessoas que já forem proprietárias, promitentes-compradores ou cessionárias de imóvel residencial na mesma localidade, não poderão adquirir imóveis objeto de aplicaçáo pelo sisterna financeiro da habitação».

Nada mais diz a lei a respeito de restriçōes aplicáveis ao ocupante.

Há, é certo, ottros fatôres que impedem o imóvel de ser alienado e o ocupante de comprar. Não são, pròpriamente, impossibilidades legais, mas, sim, implicações decorrentes de fatôres eventuais, adstritos, quer ao imóvel, quer ao ocupante. Neste caso, cabe, corretamen. te, ao decreto a prerrogativa de enumerar os implementos que ocorrerem, sem, contudo, modificar o espirito da lei.

Quanto aos imóveis são perfeitas as exceções estabelecidas nos itens do artigo $5^{\circ}$, do Decreto $\mathrm{n}^{\circ}$ 56.793-65.

E obvio, também, que não poderão ser alienados os imóveis que estão sub judice.
Entretanto não nos parece justo que se exclua, de alienação, imóvel ao qual se refere débito da taxa de ocupação ou outro qualquer, deixado por exocupante.

Quanto ao ocupante, certas razões poderão ocorrer para impedi-lo de adquirir.

Não consta da Lei $\mathrm{n}^{2}$ 4.380-64, mas seria contrário à finalidade da aquisição da casa própria consentir-se que cada componente do casal adquirisse um imóvel na mesma localidade. Um dêles seria, fatalmente, objeto de renda.

Em se tratando de pessoas juridicas, de qualquer natureza, porque seria violada a finalidade citada, a proibição, também, deve ser absoluta.

Colocada a impossibilidade legal, de que trata a lei, nos exatos têrmos, examinaremos, agora, o sentido da expressão função caracteristicamente transitória.

Qual a definição do vocábulo transitório?

«'Transitoriedade. De trânsito, exprime a qualidade, ou a condiçäo de transitório, isto é, é provisório, é temporário, está em trânsito ou está de passagem (De Plácido e Silva, vocábulo juridico, vol. IV, pág. 1.586) .

O que é função caracterìsticamente, transitória?

A rigor só poderá ser a que decorre do exercício de cargo em comissão.

Parece-nos que o pressuposto é o de que o titular dessa espécie da função nela permanece por tempo limitado. Mas, ai cabe a indagação: o que se deve considerar por tempo limitado? meses, anos?

Podendo essa transferência entenderse por tempo limitado, não nos parece justa a exclusão dêsses titulares, pela simples razão de que constitui contra. senso, quando não se excluem outros ocupantes, sem qualquer vinculo com o serviço público, cujos motivos de permanência nesta Capital poderão cessar a qualquer momento.

Pelo mesmo argumento, não devem ser excluidos os congressistas e os componentes das fôrças armadas.

Tramitando na Câmara dos Deputados, o projeto da Lei do Plano $\mathrm{Na}$ - 
cional de Habitação, que se cristalizou na Lei $\mathrm{n}^{\circ} 4.380$, de 21 de agôsto de 1964, foi, amplamente, debatido e não foram poucas as emendas que recebeu.

Dentre elas avultam as de ns. 23 e 24, da autoria do Deputado Magalhães Melo nas quais foram propostas normas restritivas ou reguladoras, relativas aos apartamentos ocupados por Congressistas, Ministros do Supremo e de Estado, Chefes da Casa Civil e Militar, Jornalistas etc.

Rejeitadas essas e tôdas as outras, que importavam em restrição à aquisição de apartamentos por êsses grupos, da lei constaram, apenas, as cautelas genéricas, indispensáveis à boa execução.

A lei não distinguindo mais do que distinguiu, não limitando mais do que limitou, não caracterizando mais do que caracterizou, não outorgou a decreto algum a prerrogativa de regulamentação restritiva, que excluísse, da compra de apartamentos, grupos numerosos de ocupantes, com sérias conseqüências para o objetivo da aquisição da casa própria, pelo sistema instituido no art. 65 , da Lei $\mathrm{n}^{\circ} 4.380-64$.

Pelos motivos expostos, propomos a substituição da Portaria $\mathrm{n}^{2}$ 42-65 por outra com esta redação:

\section{PORTARIA No 65}

O Dirigente do Grupo de Trabalho de Brasília, no uso das atribuições legais e tendo em vista o disposto no Decreto $\mathrm{n}^{\circ} 56.793$, de 27 de agösto de 1965, resolve aprovar o critério a ser adotado para execução do artigo 65 , da Lei $\mathrm{n}^{\circ}$ 4.380, de 21 de agôsto de 1964.

I - são excluídos de venda, em Brasilia, as unidades residenciais:

a) «sub judice»;

b) de propriedade da União;

c) cuja ocupação não esteja, devidamente, legalizada;

d) cujos ocupantes, qualquer dêles, fá forem proprietários, promitentes-compradores ou cessionários de imóveis residenciais em Brasilia:

e) ocupados por pessoas juridicas de direito privado ou direito público interno, estranhas à estrutura do serviço público, inclusive órgãos de representa- ção de governos estaduais, instituições religiosas, sociais etc.;

f) cuja finalidade, de residência, esteja sendo desvirtuda pelo ocupante.

II - Não poderão adquirir unidades residenciais, em Brasilia, os ocupantes:

a) sem título legitimo de ocupação, em plena vigência, expedido pęlo GTB ou entidades proprietárias;

b) em débito, para com a entidade proprietária, de taxa de ocupação ou de qualquer outra natureza, referente ao uso e gôzo de imóvel ocupado ou exocupado;

c) casados, ambos titulares de têrmos de ocupação, sem imediata opção por um dêles.

Brasilia, DF., 22 de setembro de 1965 - Igor Tenorio, Consultor Jurídico.»

\section{Subcensuta.}

Brasilia, 18 de novembro de 1965 . Adroaldo Mesquita da Costa, ConsultorGeral da República.

PR 4.560-65 - No 276.H, de 26 de novembro de 1965 - «Aprovo. Em 2-12-65» (Enc. ao M.V.O.P., em 10 de dezembro de 1965).

Assunto: As Leis ns. 3.990-61 e 4.581-64 não são inconstitucionais.

\section{PARECER}

A Rêde Ferroviária Federal S. A. entende estar desobrigada a cumprir as Leis ns. 3.990, de 7-12-61 e 4.581, de 11-12-64.

2. Alega que tais leis são inconstitucionais, por isso que atentam contra o direito de propriedade e o principio da isonomia, ambos, expressamente, garantidos pela Constituição Federal.

3. A citada Lei 3.990 prorroga as locações de prédios pertencentes à Rêde Ferroviária Federal S. A. a seus ser. vidores na ativa ou não, ou a seus sucessores, e suspende as açôes de despejo contra os mesmos propostas. Outrossim, exclui de seus efeitos as moradias consideradas gratuitas, imprescindiveis ao bom funcionamento dos serviços ferroviários.

4. A referida Lei 4.581 determina que a Rêde venda a seus ocupantes, 
desde que servidores estáveis da Rêde de Viação Cearense, as casas residenciais que integram a «Vila Demóstenes Rockert».

5. Os argumentos que servem de fundamento à alegada inconstitucionalidade são:

1. a Rêde Ferroviária Federal S.A. constitui organismo dotado de personalidade juridica própria que se não confunde com a da União, logo:

a) não pode a lei ordinária compelila a vender a terceiros bens de sua propriedade, sem violar o art. 141, §16, da Constituição Federal e, ainda, a Emenda Constitucional $\mathrm{n}^{\circ} 10$.

b) por igual, não pode a lei ordinária estabelecer norma de exceção sôbre locação de prédios residenciais de sua propriedade, sem ferir o principio constitucional da isonomia.

6. A premissa em que se assentam as conclusões mencionadas, data venia, não procede. A Rêde Ferroviária Federal S.A., a despeito de ser entidade das «mais curiosas e estranhas da administração brasileira», como bem acentuou Caio Mario da Silva Pereira, não pode ser considerada emprêsa de direito privado, para os fins pretendidos, porque:

$1^{\circ}$ explora serviço público mediante autorização da Uniẫo, que é subscritora da totalidade de suas ações;

$2^{\circ}$ suas contas e balanços estão sujeitos a parecer do Tribunal de Contas da Uniăo, na conformidade do parágrafo único do art. 34 da Lei 3.115-57, em obediência ao art. 77, inciso II, da Constituição - «julgar as contas dos responsáveis por dinheiros e outros bens públicos»;

$3^{\circ}$ a Uniăo pode intervir em suas causas judiciais;

$4^{\circ}$ os bens incorporados e que cons. tituem o seu patrimônio continuam de propriedade da Unnião.

7. Como se vê, as leis tidas como inconstitucionais não o são. A venda determinada pela Lei $\mathrm{n}^{0} 4.581$ se refere a casas residenciais que, em verdade, pertencem à União. Por outro lado, a prorrogação das locações prevista na Lei 3.990 , pelo mesmo fundamento, não viola o principio da isonomia.
8. Cumpre salientar ainda que, embora se se tratasse de emprêsa privada, no caso, melhor sorte não teria a Rêde em sua pretensão. Pontes de Miranda ensina:

«O parágrafo 16 não protege o direito de propriedade contra as emendas à Constituição... A fortiori, contra emendas às leis vigentes, para lhes extinguir direitos reais, diminuir prazos de aquisição usucapional de propriedade e prescrição de pretensões ou preclusão de direito. Ao legislador só se impede de acabar, como tal e em geral, com o instituto jurídico, com o direito de propriedade».

Disse-o muito bem o Dr. Helio Doyle, Consultor Jurídico do M.V.O.P.:

«... o direito de propriedade está sujeito a limitações de lei. No máximo, a emprêsa poderia exigir a desapropriação, com pagamento prévio. Seria um problema de opção, pois é indiscutivel $o$ interêsse social que presidiu os dispositivos legais em questão...»

9. Ainda é Pontes de Miranda que, a respeito da isonomia, preleciona:

«O parágrafo $1^{2}$ põe em relêvo a questão do conteúdo do preceito da igualdade perante a lei:

Sustenta G. Auschütz (...) que «todos são iguais perante a lei» significa que há igualdade de todos diante do juiz e da autoridade administrativa. Não se trata, ai, de igualdade da lei $(.$.$) ,$ mas de igualdade perante a leis.

10. Em conseqüência, mais uma vez concordo com o Dr. Helio Doyle, «o principio da igualdade perante a lei não impede a existência de leis especiais. Ao contrário, justifica-as, pois situações desiguais devem ser tratadas especificamente, através de lei especial».

Concluo, pois, que as Leis ns. 3.990. 61 e 4.581-64 não podem ser inquinadas de inconstitucionais.

E o meu parecer.

\section{S.M.J.}

Brasilia, 26 de novembro de 1965. Adroaldo Mesquita da Costa, ConsultorGeral da República. 
PR 12.769-65 - No 278-H, de 30 de novembro de 1965 . — «Aprovo.

Em 2-12-65». (Enc. ao DẢsP, em 10-12-65) .

Assunto: Exigência de diploma para efeito de readaptação.

- Art. $3^{\circ}$ da Lei n 4.084, de 1962. Aplicação.

\section{PARECER}

Solicitou o Departamento Administrativo do Serviço Público - DASP ao Excelentissimo Senhor Presidente da República fôsse submetido ao exame desta Consultoria Geral processo de interêsse do Instituto Brasileiro de Reforma Agrária - IBRA - onde se procura esclarecer se, na vigência da Lei $\mathrm{n}^{2} 4.084$, de 30 de junho de 1962 , que dispõe sôbre a profissão de bibliotecário e regula seu exercício, é possivel conceder-se, a funcionário que não possua o diploma de bacharel em Biblioteconomia, readaptação como Documentarista, com fundamento nos artigos 43 da Lei $n^{\circ} 3.780-60$ ou 64 , da Lei número 4.242 , de 17 de julho de 1963 .

2. Opinando sôbre a matéria, surgiram divergências de interpretação entre a Divisão do Regime Juridico do Pessoal e a Consultoria Jurid:ca daquele Departamento. As conclusões dêsses órgãos podem ser assim sintetizadas:

a) a Divisão do Regime Juridico do Pessoal é de parecer que, se os servidores das emprêsas sob intervenção governamental, ou dos concessionários do serviço público, podem continuar a exercer as atividades de bibliotecário e documentarista, sem impedimento resultante da falta de diploma, não há como aplicar-se a exigência dêsse requisito aos funcionários que se achavam já desviados de suas funções e exercendo a dos cargos em que a readaptação deve ser feita, quando entrou em vigor a lei que instituiu aquela exigência, A conclusão é, portanto, no sentido da preexistência de um direito, não afetado pela lei nova.

b) a Consultoria Juridica, por sua vez, diz que não vê como processar-se à readaptação em cargos das séries de classes de Bibliotecário e Documentaris- ta, sem que os readaptados possuam a habilitação profissional exigida em lei, desde que a ressalva dirigida aos que já ocupavam êstes cargos quando da entrada em vigor da Lei $\mathrm{n}^{0} 4.084$, de 1962, não os atinge, o que só ocorreria se a readaptação tivesse ao revés do que se acha expressamente consignado (art. 46 da Lei $n^{\circ}$ 3.780-60) efeito retroativo.

3. A Lei $n^{0} 4.084$, de 30 de junho de 1962, que dispõe sôbre a profissão de bibliotecário e regula o seu exercicio, estabelece, verbis:

«Art. $3^{\circ}$ Para o provimento e exercício de cargos técnicos de Bibliotecários e Documentaristas, na administração pública autárquica, paraestatal, nas emprêsas sob intervenção governamental ou nas concessionárias de serviço público, é obrigatória a apresentação do diploma de bacharel, em Biblioteconomia respeitados os direitos dos atuais ocupantes efetivos».

4. Vê-se, claramente, que o propósito do legislador foi, sem dúvida, prescrever uma obrigatoriedade futura, no sentido de que sòmente os bacharéis em Biblioteconomia pudessem ocupar cargos de Bibliotecário e Documentarista respeitados, contudo, os direitos dos que, àquela data, já eram ocupantes efetivos dos mencionados cargos.

5. A dúvida suscitada é sôbre até que ponto essa medida legislativa poderá interferir na aplicação do instituto da readaptação.

6. A condição de tempo do desvio funcional é de suma importância para a adoção dos critérios relativos à readaptação, por isso que o estudo dos requisitos se limitam ao prazo fixado na lei. Dai a necessidade de se relemorar que à margem de outros atributos é necessário fique comprovado que o funcionário exerceu atribuições diversas das pertinentes à classe em que foi enquadrado:

a) por prazo superior a 2 anos imediatamente anteriores à vigência da Lei $\mathrm{n}^{9} 3.780$, de 12 de julho de 1960 (art. 43) .

b) por prazo superior a 5 anos ime. diatamente anteriores a 21 de agôsto de 1959 (art. 43 da Lei $\mathrm{n}^{\circ}$ 3.780-60). 
c) por 2 anos ininterruptos antes de 17 de julho de 1963, data da Lei número 4.242, de 1963 (art. 64 dessa lei).

d) por 5 anos, com interrupção, antes da data de vigência da Lei número $4.242-63$.

1. Verifica-se, assim, que a caracterização do desvio funcional, para efeito da Lei $n^{\circ} 3.780-60$ se opera antes da vigência da Lei $\mathrm{n}^{\circ}$ 4.084-62, enquanto que, para os mesmos efeitos da Lei $\mathrm{n}^{\circ} 4.242-63$, tal desvio pode consumar-se antes ou depois da lei que regulamentou as profissões.

8. Argumenta-se que, tanto em um como em outro caso, a readaptação terá de observar os têrmos da Lei número 4.084-62, isto é, sòmente os que possuirem diploma de bacharel em biblioteconomia poderão merecer os favores da readaptação, visto que o citado diploma não permite a investidura nos cargos que menciona, sem a apresentação do competente título.

9. Realmente, a Lei $\mathrm{n}^{\circ} 4.084$ criou a exigência alegada. Resta saber se tal exigência há que ser adotada indistintamente a todos os casos de readaptações.

10. A análise rigida daquele preceito poderá levar o intérprete a êsse entendimento.

11. Entretanto, o exame do assunto não poderá relegar a segundo plano os matizes $\mathrm{e}$ as caracteristicas que norteiam o instituto da readaptação.

12. Já tive oportunidade de afirmar que a readaptação apresenta certas peculiaridades que não se confundem com outros institutos. Não depende de vaga, eis que se consubstancia numa transformação de cargos. Não está condicionada ao interêsse da administração, porque se examina a situação de fato, pretérita, do servidor (Parecer $\mathrm{n}^{2} 85$ $\mathrm{H}$, in D.O. de 18-11-64).

13. Dêste modo, não poderá prevalecer a tese de que na espécie há provimento nos cargos transformados e, para tanto, há que se exigir o certificado respectivo.

14. O provimento de que trata a lei, pode ser sòmente aquêle cujas formas são definidas no Estatuto dos Funcionários, nelas não se incluindo a readaptação.
15. $\mathrm{E}$ bem verdade que a lei menciona, de forma expressa, o exercicio, vedando-o a quem não disponha daquele requisito formal (diploma).

16. A proibição, entretanto, pode vigorar sòmente a partir da vigência da lei. Essa não pode retroagir para atingir situações anteriormente constituídas.

17. Dir-se-á, em contraposição, que, se a readaptação produz efeitos a contar da data da publicação do Decreto no Diário Oficial (art. 46 da Lei número $3.780-60)$, o exercício anterior a esta e posterior à data da Lei número 4.084-62, é irregular, vale dizer, é inconciliável com a norma contida no artigo $3^{\circ}$ dêsse diploma.

18. Não prospera o argumento. $\mathrm{O}$ funcionário que preencheu tôdas as condições prescritas na lei para ver consagrada sua readaptação, não pode vê-la denegada pela superveniência de fato legal posterior, tanto mais que o atraso na consumação daquele benefício foi causado pela própria administração.

19. A interpretação limitativa"ora defendida no processo leva ao absurdo de admitir-se critério diverso, decorrente da aplicação da mesma lei. Assim, por exemplo, se um funcionário conseguir que seu processo de readaptação tivesse sido apreciado, deferido e publicado o decreto antes da vigência da Lei número 4.084-62, estaria isento da exigência nela inserta e, por essa forma, abso lutamente correta e legal sua readaptação. Se outro funcionário, nas mesmas condições, tivesse seu processo retardado, por qualquer motivo, mesmo por inércia administrativa, de modo que só após a vigência daquela lei fôsse submetido a exame, êsse já estaria prejudicado em decorrência do nôvo texto regulamentar.

20. E manifesta a injustiça. Seriam dois pesos e duas medidas. Seria a quebra do principio constitucional de que todos são iguais perante a lei (artigo $141 \S 1^{\circ}$ da Constituição Federal) o que é defeso.

21. Assim sendo, minha conclusão é no sentido de que não se deve exigir diploma, para os servidores que completaram o periodo de desvio funcional antes da vigência da Lei $n^{\circ}$ 4.084-62. 
22. Entrementes, êsse requisito deve ser observado para os que o tenham completado após a entrada em vigor daquele permissivo, ainda que o desvio se tenha iniciado em época anterior.

E o meu parecer, s.m.j.

Brasilia, 30 de novembro de 1965 . Adroaldo Mesquita da Costa, Consultor-Geral da República.

PR. 5.734-65 - No 016 , de 27 de maio de 1965. «Aprovo. Em 6-7-65». (Enc. ao M. I. C., em 12-7-65).

Assunto: Servidores da extinta Comissão Federal de Abastecimento e Preços (COFAP), Competência da Superintendência Nacional do Abastecimento (SUNAB) para julgar atos praticados pelo pessoal pertencente ao Orgão in. corporado ex vi da Lei Delegada $\mathrm{n}^{\circ} 5$, de 1962.

Excelentíssimo Senhor Presidente da República.

Tenho a honra de restituir a Vossa Excelência o Processo $n^{\circ}$ PR-05734-65, que se encontrava em estudo nesta Consultoria Geral, onde deu origem à consulta $\mathrm{n}^{2} \quad 073-\mathrm{C}-65$.

2. O Ministério da Indústria e Comércio solicitou a audiência desta Consultoria acêrca da competência do Orgão encarregado de decidir assuntos relacionados com os servidores da extinta COFAP.

3. Surgiu o problema face ao julgamento de conclusões de inquéritos administrativos. Entendeu a SUNAB que a competência para proceder ao julgamento de tais processos é do Ministério da Indústria e Comércio, por fôrça do Decreto $\mathrm{n}^{0} 53.076$, de 4 de dezembro de 1963.

4. Submetida a matéria à apreciação da douta Consultoria Juridica do MIC, esta, através de brilhantes pareceres, considerou improcedente a argumentação da SUINẢB, por isso que, desde o advento da Lei Delegada $\mathrm{n}^{\circ} 5-62$, todos os encargos decorrentes da incorporação daquela Comissão passaram para o nôvo órgão do abastecimento.

5. O assunto, a esta altura, já não merece maiores considerações, vez que, em recente parecer, tive oportunidade de abordar a questão, quando me pronunciei sôbre o acervo da Comissão Federal de Abastecimento e Preços, ocasião em que afirmei:

«10. O problema é saber-se a que repartição pertence o acervo da extinta COFAP. Até a vigência da Lei Delegada $n^{\circ} 5-62$, não resta a menor dúvida que o mesmo pertencia ao MIC por fôrça do $\S 2^{\circ}$, da Lei 3.782-60. Com o advento do diploma delegado, entretanto, passou para o patrimônio da SUNAB, ex vi de seu art. 19.

11. Admitir-se de forma contrária seria criar o absurdo da retaliação do órgão extinto, no sentido de que todos os serviços, atribuições, responsabilidades e pessoal estariam integrados na SUNAB, excluindo-se, apenas, o acervo que ficaria com o Ministério da Indústria e Comércio.

12. A SUNAB é, na essência, a substituta da COFAP, na politica de abastecimento do Pais, como órgão do Govêrno encarregado de aplicar a legislação de intervenção no dominio econômico. Parecer $\mathrm{n}^{\circ} 155-\mathrm{H}$, In D.O. de 29-4-65».

6. A tese é válida com relação aos atos pertinentes ao pessoal da COFAP. A Lei Delegada $n^{\circ}$ 5-62 revogou as disposições da Lei $\mathrm{n}^{\circ} 3.782$, de 22 de julho de 1960 em tudo que diz respeito à antiga Comissão. A incorporação desta na estruturação do nôvo órgão da politica de abastecimento importou na transferência dos encargos - até então sob a responsabilidade do Ministério da Indústria e Comércio - à Superintendência criada.

7. Não pode impressionar a norma inserta no artigo $6^{\circ}$ do Decreto núme. ro 53.076-63 que delega competência ao MIC para decidir tôdas as questões relativas a pessoal, que digam respeito a atos praticados ou fatos ocorridos anteriormente à sua vigência.

8. Esta regra visou a disciplinar aquêles assuntos, com respeito à competência de decidir, na fase de transição, vale dizer, no periodo de organização e instalação da SUINAB. Hoje, já não cabe como regra impositiva re. gulamentar, por isso que o diploma regulamentado (Lei Delegada $\mathrm{n}^{\circ} 5$ ) não autorizou a expedição de tal preceito. 
9. A opção de que trata seu art. 24 não interfere no julgamento dos atos anteriores dos servidores dos órgãos incorporados. A competência para êsse julgamento é, sem sombra de dúvida, da SUNAB. A ligação do MIC aos assuntos da COFAP cessou com a vigência da Lei Delegada, exceção feita do pessoal que tenha optado por aquêle Ministério, na forma do art. 24 , citado.

Aproveito a oportunidade para renovar a Vossa Excelência os protestos de estima e aprêço. - Adroaldo Mesqui. ta da Costa, Consultor-Geral da República.

PR 20.546-64 - $\mathrm{N}^{\circ} 192-\mathrm{H}$, de 26 de maio de 1965. Aprovo. Em 6-7-65. (Enc. ao M.E.C., em 12-7-65).

Assunto; Professôres da Faculda de de Farmácia e Odontologia de Juiz de Fora. Solicitação de efetivação como catedráticos. Impossibi. lidade de atendimento, face a preceito constitucional. Jurisprudência do Supremo Tribunal Federal.

\section{PARECER}

Geraldo Halfeld e José Felippe Ludolf de Mello Filho, ocupantes interinos das cátedras da Clinica Odontológica, I e II cadeiras da Faculdade de Farmácia e Odontologia da Universidade de Juiz de Fora, solicitaram ao Diretor da Escola fôssem seus nomes propostos para catedráticos efetivos.

2. Em abono de suas pretensões alegaram:

«a) que, por concurso realizado naquela Faculdade, em data de 2 de janeiro de 1960, devidamente homologado pelo Exmo. Sr. Ministro da Educação e Cultura, em julho de 1960, lograram conseguir a docência livre das cadeiras de Clinica Odontológica, I e II partes, das quais era catedrático o Professor Dr. Clovis de Rezende Jaguaribe;

b) que, em virtude dos referidos concursos, entraram os suplicantes no exercício imediato de suas funções de professôres das respectivas cadeiras:

c) que, por fôrça de lei, as exigências para a prestação de concurso de
Docência Livre são as mesmas para. o Concurso de Catedrático, as quais foram integralmente satisfeitas pelos suplicantes;

d) que, em virtude de alcançar a idade limite de setenta anos, foi o catedrático efetivo, Prof. Dr. Clóvis de Rezende Jaguaribe, aposentado compulsòriamente, ficando vagas as referidas cátedras de Clínica Odontológica, I e II cadeiras;

e) que, tendo satisfeito tôdas as exigências regulamentares e legais exigiveis para o preenchimento efetivo das cátedras, liquido se torna o direito dos suplicantes em se verem aproveitados como catedráticos efetivos das referidas cadeiras, conforme torrencial jurisprudência firmada pelo Egrégio Conselho Nacional de Educação...»

3. Despachado o requerimento dos interessados, o Diretor daquela Faculdade nomeou uma comissão de três professôres para

«... estudar e dar parecer sôbre o pedido».

4. Em atenção a êsse despacho, propôs a Comissão à Congreǵação da Universidade de Juiz de Fora a undicação dos requerentes para o preenchimento efetivo das referidas cátedras.

5. Submetido o processo à consideração do Conselho Unniversitário êste, em sessão de 6 de abril de 1962

«... por maioria de votos, aprovou o parecer da douta Comissão de Legislação e Recursos, opinando pela homologação do parecer da Congregação da Faculdade de Farmácia e Odontologia da Universidade, e indicando para provimento efetivo das cátedras I e II, de Clinica Odontológica daquela Faculdade, respectivamente, os Professôres Geraldo Halfeld e José Felippe Ludolf de Mello Filho».

6. Encaminhado o processo ao Ministério da Educação e Cultura «para os fins de direito», foi ali ouvida a Consultoria Juridica que, com o parecer de fls. 23-25, concluiu:

«... Pelo exposto, chega-se à conclusão de que V. Exa. está perfeitamente à vontade para apreciar a conveniência de atender ou não à solicitaçãö da Universidade de Juiz de Fora, no sentido de promover a nomeação 
efetiva dos professôres Geraldo Halfeld e José Felipe Ludolf Mello Filho, respectivamente na I e II cadeiras de Clinica Odontológica da Faculdade de Farmácia e Odontologia.

7. Despachado o processo, o ex-titular da pasta da Educação, professor Monteiro de Barros, asseriu:

«Ciente dos têrtmos do parecer supra. O Ministro resolve ouvir, em aditamento, e com tôda urgência possivel, o Senhor Dr. Dario Delio Cardoso, agora no exercicio de Assistência e Assessoramento Jurídico. E assim procede o Ministro por lhe parecer que o mérito dêste processo envolve questões de alta indagação e de vital interêsse do ensi no superior, pelo que é de conveniência que sôbre êles se fixem diretrizes e orientação definitivas. Em verdade, o concurso a que se submeteram os interessados foi para a livre-docência e nč́o para a cátedra, sendo certo que o próprio edital de chamamento de candidato, assim deverá ter disposto. Mas da docéncia-livre à cátedra existe mais um degrau na escalada do supremo pôsto, que é o de catedrático. Tem, entretanto, havido argumentação pró e contra a tese da necessidade de nôvo concurso (da docência à cátedra), argumentação essa que impressiona a quem deva decidir. Nestas condições, determino: a) que se tome parecer do assessor juridico Dr. Dario Delio Cardoso; b) que, com êsse Gabinete, com tempo de submeter o caso ao Colendo Conselho $\mathrm{Fe}$ deral de Educação, a fim de que se procure assentar diretriz uniforme.

\section{Brasilia, 6-6-63».}

8. Examinando a matéria, o ilustre Assessor Juridico, Doutor Dario Delio Cardoso, em alentado parecer - fls. 16 usque 30 , advertiu:

$\ll \ldots$ inexiste direito liquido de acesso à cátedra em caráter efetivo, por parte dos suplicantes, uma vez que a ela não concorreram, mas à docêncialivre;

8. Não é certo que as exigências para o concurso de livres-docentes sejam idênticas às do concurso para a cáted:a. A distinção entre os dois é nitidamente feita pelo Decreto $\mathrm{n}^{\circ} 19.851$, de 11 de abril de 1931; estabelece êle normas especificas para o provimento do cargo de professor catedrático, enumerando os requisitos a que deva obedecer, ao passo que, tratando da investidura dos livres-docentes, entrega a cada instituto a competência para regular tal investidura exigindo apenas a demonstração da capacidade técnica e científica dos candidatos através de «um concurso de provas e titulos», consoante dispõe o seu art. 75.

Vê-se, portanto, que a habilitação do catedrático obedece a normas mais rigidas e rigorosas do que as exigidas para a do livre-docente.

O diploma citado não nivela os dois concursos; ao contrário, depois de regular minuciosamente o referente à cátedra, limita-se a dispor, no parágrafo único do artigo 75 , que os processos de realização e julgamento de ambos seja o mesmo.

9. Também não é exato que a jurisprudência seja torrencial no equiparar tais exigências, porquanto o próprio Supremo Tribunal Federal, em acórdão, proferido no Mandado de Segurança $\mathrm{n}^{\circ} 2.114$, de Minas Gerais, reconheceu ser o concurso para livre-docente menos amplo do que o de professor catedrá. tico e deixou claro que a livre-docência não dá obrigatòriamente acesso à cátedra. (Rev. Forense, vol. 165, página 133).

Aliás as leis reguladoras da espécie não dão margem a outra interpretação: com assento nelas, têm êles apenas o direito de substituir os professôres catedráticos nos seus impedimentos prolongados.

10. As prerrogativas outorgadas pelo titulo estão taxativamente enumeradas no art. 76 do citado Decreto $n^{\circ} 19.851$, de 11-4-1931, e são as seguintes:

a) realizar cursos equiparados;

b) substituir o professor catedrático em seus impedimentos prolongados;

c) colaborar com o professor catedrático na realização dos cursos normais;

d) reger o ensino de turmas;

e) organizar e realizar cursos de aperfeiçoamento e de especialização re. lativos à disciplina de que são docenteslivres.

11. Ainda mais: o Decreto $\mathrm{n}^{\circ} 33.460$, de 8 de agôsto de 1953, dispõe que o 
concurso de títulos e provas para preenchimento das cátedras no magistério superior vale apenas para o preenchimento das que constarem do edital, sem prejuizo da atribuição, ao candidato ou candidatos não escolhidos pelo Govêrno para a nomeação, do título do livre-docente.

12. Há, em verdade, duas espécies de docentes-livres: os que fazem concurso especialmente para essa investidura e os que recebem o titulo em virtude de haverem concorrido à cátedra e que, embora habilitados para o exercicio dela, não tenham obtido média que lhes assegure a indicação para a nc|neação, e aos quais a lei confere o grau de doutor e o título de docente-livre, (Lei $\mathrm{n}^{\circ} 444$, de 4 de junho de 1937, art. $5^{\circ}$ ).

Quanto a êstes, não se lhes pode deixar de reconhecer o direito à nomeação para catedráticos, independente de nôvo concurso; já o mesmo não acontece com os primeiros, que não visaram à cátedra mas apenas à livre-docência, que tem finalidade própria e definida na lei (art. 72 do Decreto $\mathrm{n}^{9} 19.851$, de 11-4-1931).

Se ao concurso para professor catedrático se comparasse, para todos os efeitos, inclusive os de investidura na cátedra, o de livre-docente não teria a lei estabelecido normas especiais para cada um dêles, que no caso seriam supérfluas.

E se ao intérprete não é lícito distinguir onde a lei não distingue, menos licito e curial lhe será deixar de distinguir onde a lei o faz expressamente, considerando inúteis os dispositivos consubstanciadores da distinção.

Nem vale o argumento invocado no brilhante parecer de fls. 13 a 19 , de que, sub/metendo-se à prestação de prova pública de habilitação, está o candidato quite com o dispositivo constitucio. nal (art. 166 n VI da Constituição), porquanto o que se ali exige é apenas que o provimento das cátedras no ensino secundário oficial e no ensino superior oficial ou livre se faça através de concurso de títulos e provas, isto é, que os professôres não sejam nomeados em caráter efetivo ou vitalicio sem a prestação do concurso. Não especifica, porém, o texto quais as cátedras.
Esta palavra está nêle empregada no sentido lato referindo-se a qualquer espécie de cátedra, e não apenas no significado restrito e especifico da cátedra, em oposição à livre-docência, ou a qualquer outro título que as leis ordinárias possam criar.

Existe aliás, uma tendência no sentido de se organizar o magistério superior em carreira escalonada. Se vingar essa tendência, naturalmente haverá concursos especiais para o preenchimento dos cargos de cada escalão, sem que nenhuma ofensa se faça ao disposto no referido texto constitucional.

13. Afirmar, portanto, que quem presta o concurso de títulos e provas está habilitado ao provimento efetivo de qualquer cátedra, será avançar por, sem dúvida, um despautério juridico, pois importará em declarar que quem fizer o concurso para uma cadeira da Faculdade de Farmácia e Odontologia adquirirá o direito ao provimento de qualquer cadeira nesse, como em outro estabelecimento de ensino, o que é evidentemente absurdo. O que a Constituição exige é o concurso de títulos e, provas para cada espécie de cargo do magistério, a fim de que o provimento possa ser efetivo e vitalício, como efetivo e vitalicio é o título de livre-docente, cx vi legis.

Devemos, por último, frisar que os cargos de provimento de livres-docentes nos casos de professôres catedráticos, citados no parecer de fls. 13 a 17 , se referem, pelo menos os três primeiros, a livres-docentes que concorrerem à catedra, e não apenas à livre-docência.

14. A nosso ver tem integral procedência a assertiva constante do despacho do Senhor Ministro de que existe um degrau, entre a docência-livre $e$; cátedra; e, se existe êsse degrau, é óbvio que os que desejarem a êle ascender, hão de se sujeitar às mesmas condições e exigências a que se submeteram os que o galgaram».

9. Com a remessa do processo ao Egrégio Conselho Federal da Educação, êste devolveu os autos ao Gabinete do Senhor Ministro, informando que a matéria não se enquadrava na competência daquele órgão, uma vez que se tratava de questão de ordem juridica. 
10. A vista do exposto, o titular da Pasta proferiu despacho nestes têrmos:

«Indefiro, tendo em vista o judicioso parecer do Senhor Assessor Juridico e o v. acórdão proferido em 10-6-63, pelo Supremo Tribunal Federal, em decisão unânime, no Mandado de Segurança $\mathrm{n}^{\circ} 10.882 »$.

11. Do despacho retro, pediram reconsiderações os interessados, oportunidade em que foi sugerida, pelo atual Ministro ao Exmo. Sr. Presidente da República, a audiência desta Consultoria Geral.

12. Os requerentes por estarem regendo as cadeiras, à época da federalização da Faculdade, foram, por ato do Exmo. Sr. Presidente da República, nomeados interinamente para as cátedras. São, hoje, portanto, professôres catedráticos interinos.

13. Quando emiti o Parecer $n^{\circ}$ 034 $\mathrm{H}$, publicado no Diário Oficial da União, de 7 de julho de 1964, página 5.945-7, examinei a situação dos professôres catedráticos interinos que pleiteavam efetivação nas cátedras, com apoio na Lei $n^{\circ}$ 4.054-62. Sustentei, na oportunidade, que sòmente o concurso público de provas e títulos dá acesso à cátedra vitalicia.

14. Ressaltei, naquele pronunciamento, que êsse era também o entendimento do Egrégio Supremo Tribunal Federal. Na verdade, ao ensejo do julgamento do Mandado de Segurança $\mathrm{n}^{\circ} 10.882$, do qual foi relator o eminente Ministro GONÇALVES DE OLIVEIRA, resultou assente esta ementa:

«Professor catedrático interino.

Pedido de efetivação com fundamento na Lei $n^{2} 4.054$, de 2 de abril de 1962. Sòmente por concurso de titulos e provas é possivel o provimento efetivo do cargo de professor catedrático, por exigência desenganada do antigo 168, IV , Constituição. Segurança indefetida. (o yrito é meul).»

15. Diga-se, de passagem, que êsse entendimento da Suprema Côrte, além de recente, foi tomado à unanimidade.

16. Argumentar-se-á, por certo, que os requerentes prestaram concurso público de provas e títulos e, assim, satisfeita estaria a exigência constitucional.
17. Com a devida vênia dos que pensam em contrário, entendo que o concurso de Docente-Livre é menos am plo do que o exigido para catedrático. Ora, os peticionários prestaram concurso público, de provas e titulos, especificamente para a livre-docência. Querer emprestar a êsse concurso validade de concurso para catedrático, só porque também foi de provas e titulos, pareceme interpretação demasiadamente ampla e sem amparo legal.

18. Conforme bem salientou o doutor DARIO DELIO CARDOSO, em seu brilhante e judicioso parecer, o Decreto $\mathrm{n}^{\circ} 19.851$, de 11-5-1931, estabelece normas especificas para o provimento do cargo de professor catedrático, enumerando os requisitos a que deva obedecer o concurso. E quando trata da investidura dos livres-docentes, entrega a cada órgão a competência para regular essa investidura.

19. Face ao que preceitua o parágrafo único, do artigo 75 , do Decreto $\mathrm{n}^{\circ}$ 19.851-31, apenas o processo de realização e julgamento é idêntico para ambos os concursos.

20. Bem se houve o ex-titular da Pasta da Educação ao afirmar que, entre a docência-livre e a cátedra, existe um degrau. Assim, os que desejarem ascender a êsse supremo pôsto, hão de sujeitar-se às condições e demais exigências a que se submeteram os que já o galgaram.

21. Os elementos constantes do processo em exame dão conta e falam bem alto do elevado gabarito profissional dos interessados. Quanto a êste aspecto, e se sôbre êle devesse eu opinar, não tẹia dúvidas no deferimento da pretensão. Ocorre, porém, que o pedido aqui focalizado não se ámolda à legislação $\mathrm{em}$ vigor, nem à jurisprudência dominante no judiciário.

22. Assim, face ao exposto, não encontro amparo legal para o deferimento do pedido.

É o meu parecer s.m.j.

Brasilia, 20 de maio de 1965. Adroaldo Mesquita da Costa, ConsultorGeral da República. 
$30.711-55-\mathrm{N}^{2} 194-\mathrm{H}$, de 4 de junho de 1965. «Aprovo. Em 6 de julho de 1965». (Enc. ao DASP, em 12 de julho de 1965).

Assunto: Acumulação de cargos. Conceito de cargo técnico ou cientifico inserto no artigo $3^{\circ}$ do Decreto $\mathrm{n}^{2} 35.956$, de 1954. Apreciação.

\section{PARECER}

Ao ser apreciado pela Comissão de Acumulação de Cargos a legitimidade da acumulação dos cargos de Postalista e Assistente de Professor da Cadeira de História Econômica Geral, foi levantada dúvida por aquêle Órgão, tendo em vista o Parecer $n^{\circ} 243-Z$, desta Consultoria, e a aplicação do preceito contido no art. $3^{\circ}$, do Decreto $\mathrm{n}^{\circ} 35.956$, de 1954 .

2. A matéria, preliminarmente, foi apreciada pelo Consultor Jurídico do DASP, Dr. Clenicio da Silva Duarte, que, sem entrar no mérito do caso em exame, suscitou questão de natureza juridica, inquinando de inconstitucionalidade o mencionado art. $3^{\circ}$

3. Em seu brilhante parecer, afirma o Dr. Consultor:

«6. Não havendo o legislador ordinário, quando da oportunidade da elaboração do nôvo Estatuto dos Funcionários (Lei $\mathrm{n}^{\circ} 1.711$, de 28 de outubro de 1952), conceituado o que entendia por cargo técnico ou cientifico, a essa definição não se poderia furtar o $\mathrm{Po}$ der Executivo, ao regulamentar o $\mathrm{Ca}$ pitulo I do Título IV daquele Estatuto, que trata do instituto da acumulação.

7. Fê-lo, entretanto, a que entendo, com grande infelicidade, visto que, como se verifica da redação transcrita no item 3 dêste pronunciamento, parece não haver atentado para o fato de que, existindo correlação de matérias e compatibilidade de horários, é permitida a acumulação de dois cargos públicos, desde que um dêles seja magistrado, ou técnico, ou cientifico.

8. Assim, o cargo técnico poderá não ter cunho cientifico, pelo que não se poderá exigir a aplicação nêle, necessàriamente, de «conhecimentos cientificos ou artisticos de nivel superior», como o faz o art. $3^{\circ}$ (caput) do citado Decreto $\mathrm{n}^{\circ} 35.956$, de 1954 .

9. Parece que ai se entendeu a norma constitucional como só permitido a acumulação entre cargos de magistério ou de um dêstes com outro técnico-científico, e não com outro técnico. Vale dizer, não se atinou para o fato de que - cargo poderia ser técnico sem ser científico» (os grifos são do original) .

4. Com êsse entendimento, não concordou o Senhor Diretor-Geral do DASP, enumerando, na E. M. $n^{\circ} 239$, de $30-4-65$, as razões por que não se filiava à tese defendida pelo $\mathrm{Sr}$. Consultor Jurídico. O titular daquele Departamento, após tecer algumas considerações de ordem doutrinária, assere:

«12. Dessa forma, a conceituação regulamentar de cargo técnico-científico se amolda à finalidade essencial da norma excepcional de acumulação de cargos e à doutrina esposada por renomados constitucionalistas. Não há, portanto, como falar em exorbitância do poder regulamentar.

13. Aliás, o vocábulo «técríico», na caracterização de cargo, sempre tem sido entendido em sentido restritivo. A própria sistemática vigente consagra êsse entendimento: o artigo 63 da Lei número 4.242 , de 17 de julho de 1963 , determinava nova classificação de cargos técnicos, medida essa efetivada pelo art. $9^{\circ}$ da Lei $n^{\circ} 4.345$, de 26 de junho de 1964, abrangendo tão-sòmente os cargos para cujo ingresso ou exercício seja exigido diploma de curso superior ou aplicação de conhecimentos equivalentes, conforme pronunciamentos da Consultoria Geral da República, mediante iniciativa dêste Departamento (in Diários Oficiais de 18 de setembro de 1964 e 4 de dezembro de 1964).

5. Inicialmente, a dúvida a ser dirimida é aquela que diz respetio à possibilidade constitucional de se acumular cargo de magistério com outro técnico, eliminada a vinculação de natureza cientifica ou vice-versa.

6. O art. 185 da Constituição $\mathrm{Fe}$ deral determina, verbis:

«É vedada a acumulação de quaisquer carğos, exceto a prevista no art. 96, $\mathrm{n}^{\circ} 1$, e a de dois cargos de magistério 
ou a de um dêstes com outro técnico ou cientifico, contanto que haja correlação de matérias e compatibilidade de horário».

7. Alguns autores sustentam a hipótese de acumulação de um cargo de magistério com outro de caráter técnico-cientifico, vale dizer, que êste último congregue conhecimentos de ordem técnica e científica, ao mesmo tempo.

8. Entretanto, a matéria não é pacifica, vez que outros defendem ponto de vista contrário, no sentido da separação do ramo de conhecimento que informa a natureza do cargo, isto é, técnico ou cientifico, separadamente.

9. $\mathrm{Na}$ realidade, o exame frio do texto constitucional leva-nos à impressão de se admitir aquela segunda teoria, segundo a qual a acumulação pode ser com um cargo técnico ou com um cargo cientifico, como aliás, defende o Dr. Consultor Jurídico do DASP.

10. As expressões «técnico» e «cientifico», separadas por uma conjunção alternativa «ou», é sinal de independencia das palavras, não resta a menor dúvida, principalmente quando se sabe que a lei não contém palavras ou expressões inúteis, sem sentido, sem propósito.

11. Neste aspecto estou inteiramente de acôrdo com o pensamento do Dr. Consultor Juridico do DASP.

12. Porém, ao se examinar cada caso concreto, o que venha a ser cargo «técnico», para efeito de acumulação, vamos verificar que êste não pode ser abstraido de conhecimentos científicos. $\mathrm{E}$, aí, é que estão com a razão os juristas seguidores da outra corrente doutrinária, entre êles: Themistocles Brandão Cavalcânti ( «Constituição Federal Comentada», vol. IV, pág. 151); Pondes de Miranda ( «Comentários à Constituição de 1946», vol. V, pág. 228); Alaim de Almeida Carneiro (in «Rev. Dir. Adm.», vol. 122, pág. 35).

13. E perfeitamente admissivel a interpretação lógica do art. 185 da Carta Magna, em detrimento da literal, pois que, para isso, contribuem os demais elementos constitutivos do mandamento constitucional.

14. Se se admitisse o cargo técnico com o sentido rìgidamente prático, ou seja, sem a influência de conhecimentos cientificos, isso importaria na impossibilidade material da acumulação, visto que impossivel seria o preenchimento do requisito da correlação de matérias.

15. Nesse sentido, vale ressaltar a lição de Alaim de Almeida Carneiro:

«Qualquer outra das várias acepções em que o têrmo tem sido empregado não conviria ao texto legal, nem justificaria a exigência formulada de correlação de matérias. Se o têrmo houvesse sido empregado como sinônimo de técnico, na concepção de Kant, não haveria porque falar a lei em cargo técnico e em cargo cientifico, que se confundiriam; se a acepção legitima pudesse ser aquela apontada por Cournot - para quem técnico é sinônimo de prático - não haveria porque falar em correlação de matérias, impossivel de verificar-se, se formos aceitar, com Claparede, que é técnico tudo o que concorre ao mecanismo da ação, teríamos transformada a exceção constitucional em regra, porque todos os cargos seriam técnicos.

Concluimos, pois, que cargos técnicos são aquêles para cujo desempenho $e$ mister familiaridade com determinados métodos, sistemàticamente organizados, que repousam no conhecimento cientifico, ministrado em determinada cátedra». ( $\ll$ Rev. Dir. Adm.», vol. 25, página 381).

16. Outro não é o entendimento de Carlos Medeiros Silva que, em abono de sua opinião, se ampara em consagrados dicionaristas, para afirmar:

«Segundo Cândido de Figueiredo, «técnico» é o que é «próprio de uma arte: relativo a uma ciência». O mesmo significado dá ao vocábulo Laudelino Freire, no «Grande e Novíssimo Dicionário da Lingua Portuguêsa» (Parecer número $193-T$, in $D$. O. de $4-11-52$ ).

17. Assim, no que diz respeito à caracterização de cargo técnico ou cientifico baseada em conhecimentos cientificos ou artísticos, não me parece deva ser retificado o art. $3^{\circ}$ do Decreto número $35.956-54$, pois atende aos principios doutrinários, sem ferir ou violar dispositivos legais ou preceito constitucional.

18. Quanto à parte final do referido dispositivo, que exige «conhecimentos 
cientificos ou artisticos de nivel superior» entendo perfeitamente aceitáveis os argumentos do Dr. Consultor Jurídico daquele Departamento.

19. A Constituição Federal, em seu art. 185, como também a Lei $\mathrm{n}^{\circ} 1.711$ de 1952 (Estatuto dos Funcionários) em seu art. 188 não estabeleceram disposições restritivas, como o fêz o decreto regulamentar.

20. O conhecimento que se exige do cargo técnico ou cientifico é aquêle que suficientemente preencha as condições para que o cargo seja considerado técnico ou cientifico. Mas isso não significa que tenha de ser, necessàriamente, de nivel superior. Essa hipótese não está prevista nem na Constituição nem no Estatuto dos Funcionários.

21. Teòricamente os conhecimentos pertinentes ao cargo técnico ou cientifico devem ser de nivel superior, no sentido de que seja possivel a existência de correlação de.matérias vez que, para o cargo de magistério, êsses conhecimentos, inegàvelmente, são de grau superior, ainda que a função exercida corresponda ao ensino médio (secundário).

22. É da essência do cargo de magistério essa condição. Porém, daí a exigir-se para o outro cargo acumulável (técnico ou científico), não me parece atenda o requisito aos principios estabelecidos nos diplomas hieràrquicamente superiores.

23. O fato de a Lei $n^{\circ} 4.345-64 \% \mathrm{r}$ fixado norma, classificando os cargos de nivel universitário, parece-me de somenos importância.

24. O art. $9^{\circ}$ daquela lei não representa, integralmente, o cumprimento do art. 58, da Lei 4.242-63. Aquêle diploma não contemplou todos os cargos técnicos, por isso que restringiu a classificação adotada aos cargos para cujo ingresso e exercicio fôsse legalmente exigido diploma de curso superior.

25. Demais disso, ainda não se pode aplicar dispositivo que trata especificamente de enquadramento, classificação, em matéria de acumulação de cargos. A conciliabilidade dessas regras seria o ideal, se o atual Sistema de Classificação de Cargos primasse pela perfeição, vale dizer, se êsse sistema representasse um estudo planificado, estruturado e global de todos os problemas do funcionalismo público. Porém, o que se vê é justamente o contrário, ou seja, um amontoado de regras imprecisas, falseadas que não representa a verdadeira situação do funcionalismo público nem atende aos objetivos da Administração.

26. O Plano de Classificação (Lei $\mathrm{n}^{2}$ 3.780-60) apesar da adolescência, transformou-se em um monstrengo juridico, ora permitindo benesses, como certas readaptações graciosas (ressalve-se neste aspecto o valor indiscutivel da $\mathrm{Co}$ missão de Classificação de Cargos, que nada tem a ver com o favoritismo pessoal de certas autoridades), ora entravando o desenvolvimento organo-funcional do Serviço Público. O Plano já não atende, a esta altura, às suas reais finalidades.

27. Por isso fmesmo, não encontro razões que justifiquem o entrelaçamento de normas, de modo que permita a disciplinação de uma determinada matéria. A execução de tal medida viria tumultuar, em certos casos, ainda mais, o complexo sistema instituido ṕela Lei $\mathrm{n}^{9}$ 3.780, de 1960 .

28. Assim, no que se refere à exigência constante do decreto regulamentar referente ao conhecimento de nivel superior de ensino, entendo desnecessária, porque, além de não ser autorizada pela Lei Maior ou pelo Estatuto, atualmente, face a regra do art. $9^{\circ}$ da Lei $\mathrm{n}^{\circ} 4.345$ de 1964 , poderia sèr interpretada como aplicável sòmente aos portadores dos respectivos diplomas de grau universitário, medida que não se ajusta à inspiração do texto legal. O conhecimento do nivel superior deve ser apreciado, em cada caso concreto, no momento do exame da correlação de matérias, porém, êsse elemento não deve implicar na conceituação do cargo técnico ou cientifico.

29. O ponto de vista esposado neste parecer não significa interpretação liberal do instituto da acumulação; visa, apenas, a adaptar a norma do regulamento aos preceitos constitucionais e legais. Mantenho, entretanto, a minha opinião emitida em pronunciamentos anteriores, no sentido de que a regra geral é a da proibição. As exceções só se admitem nos exatos têrmos da Constituição. Esta é a jurisprudência e a dou- 
trina predominante, cuja aplicação se impõe incondicionalmente mesmo porque reflete a nossa tradição histórica a respeito da matéria.

30. Quanto à espécie versada no processo, relacionada com o Parecer núme. ro $243-Z$, desta Consultoria, não vejo porque alterar a solução do problema. O parecer citado, da lavra do eminente Ministro Gonçalves de Oliveira, assenta-se em decisão do Egrégio Supremo Tribunal Federal (ac. no mand. de seg. $\mathrm{n}^{\circ} 1.652$ ), a qual merece todo respeito e acatamento.

E o meu parecer, s.m.j.

Brasilia, 4 de junho de 1965. Adroaldo Mesquita da Costa, ConsultorGeral da República.

PR 20.069-64 - Ne 195-H, de 4 de junho de 1965. - «Aprovo. Em 6 de julho de 1965». - (Enc. ao MEC, em 12-7-65).

Assunto - Retificação de enquadramento. Nivel Universitário. Enfermeiro. Aplicação do parecer do Conselho Federal de Educação.

\section{PARECER}

O Decreto $\mathrm{n}^{9} 54.015$, de 13 de julho de 1964 , estabeleceu a classificação dos cargos de enfermeiro no item III, de seu art. $1^{\circ}$, vale dizer, fixou o enquadramento dos niveis 19 e 20 , correspondente aos cargos para cujo ingresso ou exercicio se exige conclusão de curso universitário de duração de 3 (três) anos.

2. Contra tal classificação se insurgiram os interessados inclusive a sua associação de classe (Associação Brasileira de Enfermagem), motivo pelo qual o assunto foi apreciado pelo Grupo de Trabalho, instituido pela Portaria número 5-64, desta Consultoria Geral.

3. A pretensão não mereceu acolhida pelo mencionado Grupo, em virtude dos têrmos imprecisos do Parecer $n^{0}$ 370-64, da Câmara de Ensino Superior do Conselho Fuderal de Educação em resposta à consulta formulada pelo mesmo G.T.

4. Inconformados, insistiram os enfermeiros na revisão da matéria, agora amparados por nôvo pronunciamento do Conselho Federal de Educação (Pare- cer $\mathrm{n}^{0}$ 397-64) que eliminou as dúvidas suscitadas no parecer anterior e definiu categòricamente a situação dos profissionais da enfermagem, no que diz respeito à duração dos cursos respectivos.

5. O Departamento Administrativo do Serviço Público (DASP), apreciando o recurso interposto, pronunciou-se contràriamente ao pedido, alegando:

«7. O deferimento da pretensão das interessadas importaria, assim, em quebra da sistemática em vigor, com a inversão das normas que a inspiram, uma vez que o cargo passaria a ser classificado com base na formação pessoal do ocupante e não pela avaliaçấo de conjunto de atribuições e responsabilidades que lhe são inerentes, negando o nivel de conhecimento exigido para o respectivo exercicio» (E. M. n ${ }^{\circ} 138$, de 4 de março de 1965).

6. Baixei o processo em diligência, no sentido de ser ouvida a Diretoria do Ensino Superior, órgão especializado no assunto, que, através de parecer subs. crito por sua Diretoria Substituta, afirma:

«No Processo $\mathrm{n}^{\circ}$ 8.365-64 do DASP $\left(\mathrm{n}^{\circ}\right.$ 238.995-64 - MEC), ora apensado a êste, consta, já, um pronunciamento desta Diretoria, quando, no ofício número 25-Br. de 30 de julho de 1964 , informava ao $\mathrm{Sr}$. Diretor-Geral do DASP que:

«nos têrmos do Decreto $\mathrm{n}^{\circ} 27.426$, de 14-11-49, que regulamentou a Lei numero 775 , de $6-8-49$, a duração do curso de graduação de enfermeiro era de 36 meses, que correspondem, pois, a pouco mais de 4 anos letivos, conforme esta Diretoria já teve oportunidade de concluir».

Não deve persistir qualquer dúvida a êsse respeito, à vista do fundamento legal. Os atuais enfermeiros do Serviço Público Civil da União são possuidores de curso universitário de duraçăo determinada por lei - equivalente a 4 (quatro) anos» (grifei).

7. Na realidade, o curso de enfermagem apresentou uma série de ramificações, com durações variáveis, quer quanto à categoria, quer quanto à aplicação das várias deliberações do C.F.E.

8. Para se ter uma idéia exata do problema, mister se faz transcrever al- 
guns trechos do Parecer $\mathrm{n}^{\circ} 397-64$, daquele Conselho, e elucidativo da ques. tăo:

«Diante da dúvida levantada, a res. posta deve ser afirmativa: o curso de enfermagem de 36 meses estabelecido pelo Decreto $\mathrm{n}^{9}$ 20.109-31, a Lei número $775-49$, vigente até a aplicação da Resolução decorrente do Parecer $n^{\circ} 271$ de 1962, do C.F.E., corresponde a curso de 4 (quatro) anos letivos, de 180 dias de trabalho escolar efetivo, nos têrmos da Lei $n^{\circ} 4.024$, de 20 de dezembro de 1961. Assim, os enfermeiros diplomados no regime do Decreto número $20.109-31$ e da Lei n $775-49$ são profissionais de quatro anos de curso, para os efeitos legais.

Em resumo, a duração letiva dos cursos superiores de enfermagem e obstetrícia é a seguinte:

a) Enfermeiros formados no regime do Decreto $n^{\circ} 20 \cdot 109-31$ e da Lei número 775-49 e seu Regulamento: 4 (quatro) anos letivos.

b) Enfermeiras obstétricas (obstetrizes) formadas no regime da Lei $n^{\circ} 775$ de 1949 e seu Regulamento: 4 (quatro) anos letivos.

c) Enfermeiros formados no regime da Resolução decorrente do Parecer número 271-62 do C.F.E. : 3 (três) anos letivos.

d) Enfermeiras formadas por complementação do curso de obstetricia, nos têrmos do Parecer n ${ }^{\circ}$ 303-63: 3 (três) anos letivos.

e) Enfermeiros de Saúde Pública, formados nos têrmos do Parecer número 271-62: 4 (quatro) anos letivos.

f) Obstetrizes formadas no regime do Parecer $n^{\circ}$ 303-63: 3 (três) anos letivos.

g) Obstetrizes formadas por complementação do curso de enfermagem, nos têrmos do Parecer n 303-63: 3 (três) anos letivos.

h) Obstetrizes de Saúde Pública, formadas no regime do Parecer $\mathrm{n}^{\circ}$ 303-64, 4 (quatro) anos letivos».

9. Disso decorre a assertiva inquestionável que, à data do advento da Lei $n^{\circ} 4.345$, de 26 de junho de 1964, os enfermeiros do Serviço Público, fôsse qual fôsse a categoria profissional, eram possuidores de diplomas de nivel universitário de duração de 4 anos, formados no regime instituido pelo Decreto núme- ro $20.109-31$ e Lei $n^{\circ} 775-49$ (letras a e $b$ da conclusão do Parezer $n^{\circ}$ 397-64, do C.F.E.).

10. Com o sistema adotado pelos $\mathrm{Pa}$ receres ns. 271-62 e 303-63, a duração letiva dos cursos de enfermagem excluidos os de obstetricia, visto que nâo se lhes aplica a hipótese versada (Relatório do G.T., in D. O. de 4-12-64) passaram a ser:

-4 (quatro) anos:

Enfermeiros de Saúde Pública

- 3 (três) anos:

Enfermeiros (Parecer 271-62)

Enfermeiras formadas por complementação do curso de obstetrícia (Parecer 303-63).

11. Ressalte-se, por oportuno, que a diplomação daqueles profissionais, em decorrência dos mencionados pareceres, só ocorrerá a partir do corrente ano. Logo, inexiste atualmente, segundo o pronunciamento do órgão especializado, ocupantes de cargos públicos de enfermeiro portadores de diplomas de curso inferior a 4 anos. Todos êles. funcionários em exercício, possuem formação de 4 anos.

12. A argumentação do DASP é, até certo ponto, justificável. A classificação instituida pelo artigo $9^{\circ}$ da Lei número 4.445-64 não visa à formação pessoal, mas ao conjunto de atribuições e responsabilidades do cargo. E correto êsse entendimento, em tese, mesmo porque, se considerado de forma diferente, viria tumultuar o verdadeiro propósito legislativo, inserto no citado diploma.

13. O caso em exame, entretanto, parece-me apresentar caracteristicas especiais de modo a não o enquadrar nessa interpretação lógica e perfeita, emitida pelo DASP.

14. Ora, a classificação determinada pelo Decreto $\mathrm{n}^{\circ}$ 54.015-64, incluindo os enfermeiros na relação dos cargos de curso de 3 (três) anos, importa na negação não só do direito dos formados no regime do Decreto $\mathrm{n}^{9} 20 \cdot 109-31$ e Lei $\mathrm{n}^{\circ} 775-49$ - curso de 4 anos - e todos êles o são até o momento, como implicaria na redução do valor profissional dos que, de agora em diante, serão graduados como Enfermeiros de Saúde Pública - curso, também, de 4 anos. 
15. A tese do Departamento Administrativo do Serviço Público ainda poderia ser considerada, na espécie, se a partir de junho de 1964 (data da Lei $n^{0} 4.345$ ) todos os currículos de enfermagem fôssem fixados em 3 anos. Mas isso não ocorrerá, visto que o curriculo de Enfermeiro de Saúde Pública permanece fixado em 4 anos.

16. A classificação efetuada desconhece as situações dos atuais ocupantes e nega o valor de alguns futuros, para só admitir, com acêrto, uma área restrita que, errôneamente, vai envolvendo as outras.

17. Demais disso, não podia prevalecer a teoria do enquadramento em 3 anos - curriculo estabelecido através de parecer, embora de competência autorizada por lei - em detrimento da duração de 4 anos, disciplinada, expressamente. em diplomas de fôrça legislativa (Decreto $\mathrm{n}^{\circ}$ 20.109-31 e Lei $\mathrm{n}^{\circ}$ 775-49).

18. Nestas condições, ante o exposto, entendo cabivel o deferimento da pretensão, no sentido de ser incluida a série de classes de Enfermeiro, nos niveis 20, 21 e 22 , isto é, que dita série de classes seja relacionada no item II, do art. $1^{\circ}$ do Decreto $\mathrm{n}^{\circ}$ 54.015-64.

É meu parecer, s.m.j.

Brasilia, 4 de junho de 1965. Adroaldo Mesquita da Costa, ConsultorGeral da República.

PR 6.456-65 - N $\mathrm{N}^{\circ} 203-\mathrm{H}$, de 13 de junho de 1965. «Aprovo. Em 6 de julho de 1965». (Enc. ao MEC, cm 12-7-65).

Assunto: Ato Institucional. Demissão como conseqüência da suspensão dos direitos politicos. Autoridade competente para baixar o ato.

\section{PARECER}

A Universidade do Rio Grande do Sul solicitou ao Ministério da Educação e Cultura esclarecimentos sôbre como proceder em relação a três servidores (dois professôres e um instrutor de ensino superior) que tiveram suspensos seus direitos politicos, não havendo, ainda, se consumado a medida demissória.
2. No MEC o assunto mereceu pronunciamento de sua douta Consultoria Jurídica, através do qual foram suscitadas dúvidas a respeito da questão.

3. A primeira relaciona-se com a penalidade funcional aplicável aos atingidos pelo Art. 10 do Ato Institucional, vale dizer, aos que tiveram os direitos políticos suspensos.

4. Sôbre êste aspecto, creio não seja preciso maiores consideraçôes, vez que, pelo Ofício-Parecer $\mathrm{n}^{9} 7$, publicado no Diário Oficial de 2-4-65, pág. n 3.891 , a matéria foi devidamente apreciada.

5. Conclui o citado parecer que a suspensão dos direitos politicos, prevista no art. 10, traz, como consequêencia, a demissão pura e simples do funcionário, mesmo vitalicio ou estável, em virtude de sua motivação muito mais grave que a prevista no art. $7^{\circ}$.

6. Ressaltei, também, que houve casos em que o Senhor Presidente da República aplicou pena mais branda (aposentadoria, reforma, disponibilidade) aos que tiveram os direitos politicos suspensos. Lembrei, na oportunidade, que, na falta de ato expresso, neste sentido, a demissão se impõe, independentemente de investigação, ainda que sumária.

7. Como se vê, na espécie, as diretrizes a seguir, no que concerne ao ato punitivo de natureza administrativa, são as focalizadas no Ofício-Parecer $\mathrm{n}^{0} 7$.

8. Quanto à autoridade competente para expedir os atos de demissão, uma vez que os mesmos não foram providenciados no periodo previsto no Ato Institucional, quando coube ao Presidente da República a expedição de todos êles, parece-me que, agora, a atribuição é da autoridade que detém o poder de nomear.

9. As demissões, neste sentido, em conseqüência de suspensão dos direitos politicos, são atos meramente declaratórios, visto que a situação resultante daquela medida é incompativel com o exercício do cargo público.

10. Suspensos os direitos politicos de um cidadão, automàticamente surge a incompatibilidade com o exercicio da função pública.

11. O Senhor Presidente, no uso de faculdade sua, expediu 0 ato de penalidade (decreto de suspensão). Portan- 
to, a conseqüência administrativa disso decorrente (demissão) deve ser formalizada pela autoridade competente para nomear, que, inclusive, pode ser o próprio Presidente da República, conforme a hipótese de provimento.

12. Nem se diga que já não cabe a expedição de tais atos, por isso que já se exauriram os efeitos do artigo $7^{\circ}$ do Ato Institucional. A demissão se impõe, agora, não com fundamento nos artigos daquele Ato, mas em decorrência de suspensão dos direitos politicos, que importa na negação de uma das qualidades essenciais para o exercício do cargo. São atos meramente declaratórios, como atrás afirmei e, assim, a qualquer tempo podem ser baixados.

13. Note-se, ainda, que a adoção dessa tese não significa a retificação dos atos que apresentaram, reformaram ou colocaram em disponibilidade. Se o Presidente da Republica preferiu aquelas penalidades à demissão, fê-lo no uso de sua competência institucional, e elas não merecem revisões, máxime com o propósito de agravá-las.

E o meu parecer, s.m.j.

Brasilia, 18 de junho de 1965 - Adroaldo Mesquita da Costa, Consultor-Geral da República.

PR 7.633-65 - N $310-\mathrm{H}$, de 2 de julho de 1965. «Aprovo. Em 6-7-65».

Assunto: Acumulação de proventos de professor universitário com vencimentos do cargo de Secretário de Estado. É liciła, se, na atividade, a acumulação dos cargos fôr legalmente cabivel.

\section{PARECER}

O Senhor Governador do Estado do Rio Grande do Sul encaminhou ao Ex- celentíssimo Senhor Presidente da República expediente no qual solicita a audiência desta Consultoria Geral.

2. Trata-se da situação do Professor Bernardo Geisel, aposentado, exercendo atualmente as funções de Secretário de Estado dos Negócios da Energia e Comunicações.

3. Deseja o ilustre Governador saber se é legalmente permitida a percepção dos proventos, como professor universitário, com estipêndios deferidos aos titulares de cargos de Secretário de Estado, sem infringência das normas vedadoras da acumulação de cargos.

4. Não há que se falar, na espécie, em acumulação de cargos, visto que não se trata de ocupação de dois cargos, mas de um cargo de Secretário de Estado, com percepção de proventos decorrentes da qualidade de inativo.

5. Embora versando sôbre acumulação de proventos com remuneração de cargo, as regras disciplinadoras da matéria obedecem aos mesmos princípios estabelecidos para acumulação de cargos.

6. Aliás, sôbre assunto idêntico, esta Consultoria Geral já teve oportunidade de manifestar sua opinião, afirmando:

«Em conclusão, parece-me que o inativo só pode acumular os proventos de sua inatividade com vencimentos de cargo em comissão, quando os cargos sejam acumuláveis na atividade. Em caso contrário, deverá optar por um outro estipêndio» (Parecer $\mathrm{n}^{\circ}$ 066-H, D. O. de 9-10-64).

E o meu parecer, s.m.j.

Brasilia, 2 de julho de 1965.-Adro. aldo Mesquita da Costa, Consultor-Geral da República. 